\title{
Pemberdayaan masyarakat kawasan industri pertambangan melalui penyelenggaraan program paket $\mathrm{C}$
}

\author{
Muhamad Ali Salman *, Entoh Tohani \\ Program Studi Pendidikan Luar Sekolah, Universitas Negeri Yogyakarta. \\ Jalan Colombo No. 1, Karangmalang, Yogyakarta 55281, Indonesia \\ * Corresponding Author. Email: alisalmanmuhammad@gmail.com \\ Received: 15 February 2019; Revised: 1 July 2019; Accepted: 11 July 2019
}

\begin{abstract}
Abstrak
Tujuan penelitian untuk mengetahui pelaksanaan dan hasil dari penyelenggaraan program paket $C$ dalam upaya memberdayakan masyarakat kawasan industri pertambangan batubara di Kampung Tumbit Dayak. Jenis penelitian adalah penelitian deskriptif kualitatif. Sumber data diperoleh dari, wawancara, observasi dan analisis dokumen. Teknik analisis data menggunakan reduksi data, display data dan verifikasi data. Teknik keabsahan data menggunakan triangulasi sumber. Hasil penelitian menunjukkan bahwa, (1) pelaksanaan: Diselenggarakan sesuai syarat proses pembelajaran paket $C$ yang disusun oleh pemerintah berdasarkan Undang-Undang No 3 Tahun 2008, Rencana Pelaksanaan Pembelajaran (RPP) diimplementasikan sesuai rancangan awal, kurikulum bersifat situasional (masih menggunakan KTSP) karena belum ada sosialisasi terkait kurikulum baru, terjadi interaksi yang baik antara tutor dan peserta didik (terjadi komunikasi dua arah antara tutor dan peserta didik, peserta didik aktif untuk bertanya), sarana dan prasarana sesuai kebutuhan dan mendukung proses pembelajaran, (2). Hasil program; terjadi perubahan pada sikap peserta didik (disiplin dan percaya diri), peserta didik yang mengikuti peraturan dan prosedur PKBM dapat lulus dan memperoleh ijazah lalu bekerja di perusahaan (PT.PAMA), peserta didik mampu memenuhi kebutuhan pokok untuk diri sendiri dan juga memenuhi kebutuhan pokok keluarga.
\end{abstract}

Kata Kunci: pemberdayaan masyarakat, Program Paket C

\section{Community empowerment of mining industry areas through certification of package $C$ programs}

\begin{abstract}
The research objective was to determine the implementation and results of the implementation of the package $C$ program in an effort to empower the community of the coal mining industry in Tumbit Dayak Village. This type of research is a qualitative descriptive study. Data sources were obtained from, interviews, observation and document analysis. Data analysis techniques using data reduction, data display and data verification. Technique of data validity using source triangulation. The results showed that: (1) implementation: Organized according to the implementation requirements of package C compiled by the government based on Law No. 3 of 2008, the RPP was implemented according to the initial design, the curriculum was situational (still using KTSP) because there was no socialization regarding the latest curriculum, there is good interaction between tutors and students (there are two-way communication between tutors and students, active students to ask questions), facilities and infrastructure as needed and support the learning process, (2). Program results; there is a change in the attitude of students (discipline and self-confidence), students who follow the rules and procedures of PKBM have passed and obtained a diploma and work in a company (PT. PAMA), students are able to meet basic needs for themselves and also fulfill basic needs family.
\end{abstract}

Keywords: community empowerment, Package C program

How to Cite: Salman, M., \& Tohani, E. (2019). Pemberdayaan masyarakat kawasan industri pertambangan melalui penyelenggaraan program paket C. JPPM (Jurnal Pendidikan dan Pemberdayaan Masyarakat), 6(2), 100-110. doi:https://doi.org/10.21831/jppm.v6i2.23626

do

https://doi.org/10.21831/jppm.v6i2.23626 
JPPM (Jurnal Pendidikan dan Pemberdayaan Masyarakat), 6 (2), 2019 - 101

Muhamad Ali Salman, Entoh Tohani

\section{PENDAHULUAN}

Undang-Undang nomor 20 tahun 2003 Pasal 13 ayat 1 menyatakan bahwa jalur pendidikan terdiri dari pendidikan formal, nonformal dan informal (Presiden Republik Indonesia, 2003). Pembagian ketiga jalur pendidikan saling bersinergi dan melengkapi guna mewujudkan pemerataan pendidikan. Penyebaran pendidikan di Indonesia harus menyentuh masyarakat secara menyeluruh, baik di wilayah perkotaan maupun perkampungan yang sulit dijangkau. Penyelenggaraan ketiga jalur pendidikan diharapkan dapat memberi kapasitas bagi seluruh masyarakat Indonesia agar dapat bekerja sehingga mampu memberdayakan diri.

Indonesia sebagai negara kepulauan terbentang luas dan memiliki banyak wilayah potensial, kaya sumber daya alam yang seharusnya dapat dimanfaatkan dan dirasakan langsung oleh warga negaranya. Salah satu wilayah potensial Indonesia adalah kampung Tumbit Dayak. Lokasi Kampung Tumbit Dayak terletak di Kecamatan Sambaliung, Kabupaten Berau, Provinsi Kalimantan Timur. Daerah ini memiliki luas 81, 19 hektar dengan 117,2043 bujur timur dan 2,0032 lintang selatan. Dari data BPS Kabupaten Berau tahun 2016 diketahui bahwa masyarakat Kampung Tumbit Dayak memiliki jumlah penduduk sekitar 1288 jiwa. Mata pencaharian masyarakat pada umumnya adalah bertani, berladang dan beternak (Badan Pusat Statistik Kabupaten Berau, 2016b).

Kampung Tumbit Dayak memiliki potensi batubara yang cukup tinggi. Awal tahun 2016 perusahaan pertambangan batubara, PT. PAMA mulai beroperasi di Kampung Tumbit Dayak. Keberadaan Perusahaan PT. PAMA memikat warga dari luar Kampung Tumbit Dayak untuk bekerja, karena gaji yang diberikan pihak perusahaan cukup tinggi. Sehingga jumlah pekerja dari luar terus bertambah sedangkan masyarakat lokal masih banyak yang tidak dipekerjakan dan memiliki pendapatan rendah, terutama masyarakat yang tidak memiliki pendidikan sampai SMA/sederajat sebagai syarat utama bekerja di PT. PAMA. Hal ini disebabkan masalah pendidikan yang dialami masyarakat Kampung Tumbit Dayak. Fasilitas pendidikan yang tersedia di Kampung Tumbit Dayak masih minim, hanya memiliki 3 SD, 1 TK dan 1 SMP sedangkan SMA belum ada sehingga menyulitkan masyarakat lokal untuk mengenyam pendidikan sampai pada tingkat menengah atas. Masyarakat Tumbit Dayak yang ingin melanjutkan sekolah pada jenjang SMA, harus ke Kota Tanjung Redeb yang berjarak sekitar 1 jam perjalanan atau memilih SMA yang berada di Kecamatan sebelah (Kecamatan Teluk Bayur), namun kondisi jalan juga sama menyulitkan masyarakat. Terdapat jalan-jalan rusak, jarak tempuh sekitar 40 menit, lalu ketika musim penghujan, jalur perjalanan menjadi licin dan kotor. Kondisi ini menyebabkan jumlah masyarakat putus sekolah menjadi cukup tinggi. Hal ini dapat disingkronkan dengan data BPS tentang angka partisipasi sekolah terendah di Kabupaten Berau pada tahun 2016 adalah pada jenjang SMA dengan persentase 92,05 turun menjadi 66,20 (Badan Pusat Statistik Kabupaten Berau, 2016a).

Pemanfaatan kawasan industri pertambangan batubara di Kampung Tumbit Dayak cukup banyak berdampak bagi masyarakat lokal. Masalah ini sesuai dengan pernyataan (Sopandi, 2002) bahwa perkembangan industri mengakibatkan sebagian besar masyarakat tergusur akibat perubahan dan masuknya sektor industri, dan termarjinalisasinya masyarakat desa akibat ketidaksiapan dalam menghadapi perubahan yang terjadi dan pola pemanfaatan peluang yang ada di sektor industri.

Solusi terkait masalah pendidikan formal dan kesempatan kerja yang dialami masyarakat kawasan industri pertambangan Kampung Tumbit Dayak dapat diatasi melalui penyelenggaraan program pendidikan nonformal. Penyelenggaraan program pendidikan nonformal bertujuan memberikan kemampuan kepada masyarat berupa pengetahuan dan keterampilan. Lebih lanjut (Tohani, 2009) menyatakan bahwa program pendidikan nonformal mampu menjadikan warga belajar menguasai pengetahuan dan keterampilan yang dapat digunakan untuk meningkatkan kualitas hidupnya.

Pusat Kegiatan Belajar Masyarakat (PKBM) Pusaka Indonesia adalah sembilanbelas dari satu PKBM yang sampai saat ini 


\section{JPPM (Jurnal Pendidikan dan Pemberdayaan Masyarakat), 6 (2), 2019 - 102}

Muhamad Ali Salman, Entoh Tohani

tetap aktif menyelenggarakan program pendidikan nonformal dan pemberdayaan masyarakat. PKBM Pusaka Indonesia sebagai satu-satunya PKBM di Kabupaten Berau yang berani memulai program pendidikan nonformal di daerah perkampungan atau kawasan industri pertambangan. PKBM Pusaka Indonesia memilih inisiatif untuk bekerjasama dengan Aparat Kampung serta perusahaan (PT. PAMA) dalam upaya mengatasi masalah masyarakat Kampung Tumbit Dayak. Cara ini serupa dengan pendapat (Oktiwanti, Danial, \& Syaefuddin, 2017) bahwa Lembaga pendidikan nonformal dapat bekerjasama dengan CSR Perusahaaan jika lembaga tersebut mampu menawarkan program yang dibutuhkan dan bermanfaat secara fungsional oleh masyarakat sesuai dengan harapan perusahaan dan pemerintah sehingga mampu meningkatkan keberdayaan masyarakat.

PKBM Pusaka Indonesia bersama aparat kampung dan pihak Perusahaan memulai program dengan melakukan sosialisasi. Sosialisasi program merupakan titik awal yang menentukan keberhasilan program dalam mencapai tujuannya (Haruna, 2018). Masyarakat diundang untuk terlibat secara langsung dan melihat sejauh mana urgensi program. Kehadiran masyarakat turut membantu lembaga pendidikan nonformal dan aparat kampung untuk melihat lebih dalam konteks program dan masukan masyarakat secara langsung.

Penyelenggaraan program paket $C$ mendapatkan respon positif dari masyarakat dan sangat diminati. Faktor kebutuhan menjadi alasan masyarakat karena dapat dimanfaatkan untuk memperoleh ijazah lalu masuk ke Perusahaan (PT.PAMA) sedangkan lokasi untuk memperoleh ijazah melalui sekolah formal terlalu jauh, selain itu biaya program dibantu oleh pihak Perusahaan. Hal ini senada dengan pernyataan (Kurniawati, 2017) bahwa faktor utama yang mempengaruhi peserta didik memilih program adalah harga, program, dan lokasi.

Berdasarkan masalah yang dialami masyarakat kawasan industri pertambangan, maka penelitian ini bertujuan untuk mengetahui pelaksanaan dan hasil dari penyelenggaraan paket $C$ dalam upaya memberdayakan masyarakat Kawasan industri pertambangan Kampung Tumbit Dayak Kabupaten Berau.

\section{METODE}

Jenis penelitian menggunakan pendekatan deskriptif kualitatif. Menurut (Sukmadinata, 2009, p. 18) bahwa penelitian deskriptif bertujuan mendefinisikan suatu keadaan atau fenomena secara apa adanya. Maka penelitian ini dilakukan untuk mengetahui kondisi real program, mulai dari pelaksanaan sampai dengan hasil penyelenggaraan program paket $C$, apakah sudah sesuai dengan standar dan ketentuan yang berlaku, lalu hasilnya apakah memberikan perubahan pada masyarakat dan apakah dapat memberdayakan masyarakat di Kampung Tumbit Dayak.

Sumber data diperoleh dengan cara (1). Wawancara, peneliti mewawancarai peserta didik, tutor, dan pengurus PKBM, (2). Observasi, peneliti melakukan observasi di Kampung Tumbit Dayak dengan melihat kondisi jalan dari Kota Tanjung Redeb ke Kampung Tumbit Dayak. Melihat kondisi perkampungan Tumbit Dayak, sarana dan prasarana yang tersedia dalam kegiatan penyelenggaraan program paket $C$, serta Kantor PKBM yang berada di Kota Tanjung Redeb. (3) Dokumen, Sumber data yang digunakan untuk melengkapi penelitian adalah dengan melihat berkas yang ada, seperti: Kurikulum, SKL dan foto terkait penyelenggaraan program paket $\mathrm{C}$.

Teknik keabsahan data menggunakan triangulasi sumber. Data yang diperoleh saling disingkronkan dan disesuaikan dengan informasi temuan. Data dicari melalui berbagai sumber untuk melihat tingkat keabsahannya, melalui wawancara dengan melibatkan lebih dari satu informan supaya informasi lebih akurat. Data disesuaikan dengan hasil observasi langsung, untuk melihat kesesuaian antara pernyataan informan dengan kondisi nyata di Lapangan. Data kemudian diperkuat melalui analisis dokumen sehingga data yang dihasilkan dapat dipertanggungjawabkan dan mewakili aspek-aspek yang diteliti.

Teknik analisis data yang digunakan pada penelitian ini berdasarkan pada pendapat (Miles, Huberman, \& Saldaña, 2014; Prasetyo, 2015) bahwa ada empat komponen 


\section{JPPM (Jurnal Pendidikan dan Pemberdayaan Masyarakat), 6 (2), 2019 - 103}

Muhamad Ali Salman, Entoh Tohani

yang dilakukan ketika melakukan analisis data (pengumpulan data, reduksi data, display data dan reduksi data. Data hasil wawancara, observasi dan dokumentasi penelitian dikumpulkan. Data lalu disimpan sebagai catatan yang berisi informasi sesuai kebutuhan penelitian. Tahap selanjutnya data direduksi untuk memilah-milih hal-hal pokok, memfokuskan pada hal-hal penting dan membuang yang tidak perlu. Reduksi data pada penelitian ini difokuskan pada hasil wawancara informan yang pernyataanya mewakili aspek yang diteliti, observasi lapangan dan analisis dokumentasi. Setelah direduksi data dilakukan, maka langkah berikutnya adalah mendisplay data, menyajikan data dalam pola sesuai fokus penelitian. Display dilakukan untuk memahami konteks pelaksanaan program, mencari makna dari berbagai macam data dan melihat kondisi sosial sehingga hasilnya dapat digunakan merencanakan tahap selanjutnya. Verifikasi kemudian dilakukan untuk menarik sebuah kesimpulan berupa temuan baru yang sudah teruji dan dikontruksikan dengan hasil penelitian.

\section{HASIL DAN PEMBAHASAN}

Penyelenggaraan program paket $\mathrm{C}$ di Kampung Tumbit Dayak tidak terlepas dari hubungan kerjasama antara lembaga pendidikan nonformal yakni PKBM Pusaka Indonesia bersama aparat Kampung dan pihak perusahaan yang menangani bantuan CSR. PKBM Pusaka Indonesia sesuai visinya, berorientasi ke depan dengan potensi kekinian, berusaha mewujudkan masyarakat yang mampu meningkatkan taraf hidup dengan memanfaatkan potensi sekitar sehingga dapat meningkatkan kualitas hidupnya. Aparat kampung sebagai pengurus Kampung melihat kondisi yang dialami masyarakat secara langsung perlu memberikan penanganan melalui bantuan Lembaga yang bergerak di bidang pendidikan. Perusahaan yang beroperasi di kawasan perkampungan perlu memberikan kontribusi berupa bantuan bagi masyarakat sesuai tanggung jawab sosialnya melalui bantuan CSR.

Pembahasan dilakukan sesuai hasil temuan lapangan dan peraturan pemerintah serta kajian teori. Pembahasan mengenai pelaksanaan program paket $C$ tentang syarat- syarat yang sudah dipenuhi PKBM, implementasi kurikulum dan kondisi pada saat proses pelaksanaan kegiatan. Kemudian pembahasan mengenai kajian hasil program paket $C$ dalam upaya memberdayakan masyarakat Kampung Tumbit Dayak dengan melihat beberapa aspek, yaitu tentang perubahan yang terjadi pada peserta didik, pemenuhan kebutuhan peserta didik dalam konteks pemberdayaan masyarakat.

\section{Pelaksanaan Program Paket C}

Pelaksanaan program paket $C$ sesuai dengan jadwal yang sudah ditentukan. Tidak ada hambatan yang berarti, sehingga jadwal awal berjalan dengan lancar. Informasi ditemukan melalui pengurus PKBM, bahwa jumlah rombongan belajar peserta didik mencapai dua ratus orang, tetapi kemudian dibagi perrombongan menjadi sekitar tiga puluh orang perkelas. Informasi kemudian dipertegas melalui pernyataan salah satu tutor bahwa, pada saat proses pembelajaran jumlah peserta didik benar terdiri dari tiga puluh orang. Informasi tentang jumlah peserta didik juga terdapat di dalam dokumen absensi tutor dan peserta didik yang sudah ditandatangani. Tertulis jumlah peserta didik sebanyak tiga puluh orang perkelas. Peran tutor begitu vital, karena terlibat langsung dalam proses pembelajaran. Sehingga perlu standar pemilihan khusus bagi pendidik/ tutor. Berdasarkan keterangan pengurus yang ikut serta dalam proses penerimaan tutor. Menyatakan bahwa pemilihan tutor melalui beberapa prosedur, tutor dipilh dari latar belakang akademik, baik sebagai pengajar tetap di PKBM maupun pengajar di Sekolah formal yang memiliki jadwal mengajar yang kurang dan memanfaatkannya sebagai tambahan pendapatan. Rapat pengurus diadakan untuk memilih tutor yang siap diterjunkan kedaerah perkampungan. Tutor sesuai dengan bidang mata pelajaran yang diajarkan. Selain itu, pengalaman mengajar tutor juga menjadi pertimbangan agar memiliki kompetensi yang memadai. Keterangan diperkuat melalui data absensi yang menunjukkan gelar kesarjanaan tutor, sebagai bukti bahwa tutor lulusan sarjana pendidikan.

Tutor kemudian bertugas menjadi perancang pembelajaran. Tutor melaksanakan 


\section{JPPM (Jurnal Pendidikan dan Pemberdayaan Masyarakat), 6 (2), 2019 - 104}

Muhamad Ali Salman, Entoh Tohani

tutorial 2-3 kali dalam seminggu. Jadwal tutorial menyesuaikan kondisi lapangan atau atas permintaan masyarakat. Jika disesuaikan dengan data yang terdapat pada Rencana Pelaksanaan Pembelajaran (RPP), bahwa jadwal tutorial dirancang selama 2-3 kali pertemuan dalam seminggu. Sedangkan syarat pelaksanaan tutorial diselenggarakan minimal dua hari perminggu, jadi dapat dikatakan bahwa tutor sudah membuat dan melaksanakan jadwal tutorial sesuai standar.

Proses pembelajaran membutuhkan sarana dan prasarana sebagai fasilitas pendukung. Sarana dan prasarana sebagai syarat mutlak harus dimiliki PKBM guna dapat terselenggaranya program kegiatan. Sebagaimana yang dinyatakan oleh (Katang, Rumapea, \& Lumolos, 2016) bahwa Salah satu syarat yang harus dipenuhi dalam pendirian PKBM adalah ketersediaan sarana dan prasarana. Secara rinci (Firdausya, 2016) menyatakan, sarana prasarana yang minimal harus ada pada kegiatan program paket $C$ yaitu pertama, ruangan untuk proses pembelajaran dan pelatihan beserta kelengkapannya; kedua, alat dan bahan pembelajaran seperti whiteboard/ papan tulis, spidol/kapur, meja dan kursi tutor, meja/kursi warga belajar, lemari buku, buku-buku pelajaran, dan lainlain; dan ketiga, media pembelajaran dan pendukung lainnya.

Dokumen penting yang ditemukan terkait sarana dan prasarana adalah Memorandum of Understanding (MoU). Di dalam $M o U$ tertulis perjanjian antara pihak PKBM dan perusahaan, bahwa kedua belah pihak sepakat bekerjasama dalam hal fasilitas sarana dan prasarana yang dapat digunakan pada saat pelaksanaan program paket $C$. Ketersedian sarana dan prasarana dapat juga dilihat dari hasil foto dokumentasi. Terdapat pada gambar peserta didik sedang belajar di dalam gedung, duduk di atas kursi lengkap dengan meja di hadapannya, sedangkan tutor mendapatkan fasilitas kursi, meja serta papan tulis yang digunakan sebagai fasilitas penunjang pembelajaran.

Informasi dan data tentang sarana dan prasarana pada saat pelaksanaan program paket C di Kampung Tumbit Dayak sesuai dengan Peraturan Menteri Pendidikan Nasional Republik Indonesia Nomor 3 Tahun 2008 tentang standar proses pendidikan kesetaraan, program paket $C$ (Menteri Pendidikan Nasional Republik Indonesia, 2008). Ada beberapa persyaratan yang harus dipenuhi lembaga/instansi ketika program telah dilaksanakan, yakni: jumlah maksimal peserta didik perrombongan belajar program Paket $C$ setara SMA/MA: tiga puluh peserta didik. Penetapan jumlah tersebut disesuaikan dengan kemampuan dan ketersediaan sumber daya satuan pendidikan, lalu penyelenggara berkewajiban menyediakan pendidik sesuai dengan tuntutan mata pelajaran, jadual tutorial minimal dua hari per minggu, sarana dan prasarana pembelajaran, dan buku teks pelajaran, modul dan sumber belajar lain.

\section{Implementasi RPP}

Pelaksanaan program paket $\mathrm{C}$, khususnya pembelajaran tidak terpisahkan dari penyusunan RPP sebagai pedoman pelaksanaan pembelajaran. Temuan di lapangan menunjukan bahwa Pelaksanaan pembelajaran merupakan implementasi dari RPP yang disusun sebanyak dua belas RPP mengikuti setiap mata pelajaran. RPP disusun dengan menggunakan alokasi waktu 16 x 45 menit. Setiap pertemuan, selalu terdapat kegiatan pendahuluan, kegiatan inti dan kegiatan penutup. Informasi tambahan diperoleh melalui berkas RPP yang digunakan oleh salah satu tutor ketika mengajar. Terlihat RPP mata pelajaran sosiologi kelas X semester 1 .

Tahap pertama pertemuan adalah pendahuluan, ialah awal pengenalan tutor dengan peserta didik. Setelah melewati tahap pengenalan, maka kemudian terdapat kegiatan inti: peserta didik mulai mendengarkan ceramah dari tutor tentang hakikat ilmu, sejarah perkembangan ilmu sesuai dengan kebutuhan dan materi mata pelajaran. Metode pembelajaran dilakukan dengan tatap muka.

Peralatan atau perangkat belajar berupa buku paket kelas, lalu peserta didik mengerjakan tugas-tugas sebagai bagian dari penilaian. Pada pertemuan berikutnya peserta didik mengumpulkan tugas-tugasnya untuk diberikan penilaian oleh tutor. Kegiatan akhir adalah pemberian tes, tutor memberikan tugas kepada peserta didik untuk diselesaikan secara individu atau dengan tugas 


\section{JPPM (Jurnal Pendidikan dan Pemberdayaan Masyarakat), 6 (2), 2019 - 105}

kelompok. Pertemun berikutnya tutor mengarahkan peserta didik untuk membentuk kelompok diskusi kemudian membahas masalah-masalah yang diangkat sesuai dengan tema, lalu peserta didik membacakan hasil diskusi kelompoknya, kemudian peserta didik yang lain memberikan umpan balik berupa pertanyaan dan sanggahan dari hasil diskusi kelompok. Tutor hanya berperan sebagai pemandu yang mengarahkan jalannya diskusi kelompok agar berjalan dengan kondusif.

Kegiatan akhir adalah refleksi dari tutor. Tutor menyampaikan kesimpulan terkait pembahasan yang dianggap masih belum selesai atau tidak dipahami peserta didik. Kegiatan selanjutnya Peserta didik diberi tugas mengerjakan soal-soal akhir Bab sebagai ulangan Blok. Tutor memberikan tugas kepada peserta didik untuk mempelajari bahan pelajaran yang sudah tersedia.

Secara umum implementasi RPP meliputi, kegiatan awal: melakukan Absen tutor dan peserta didik, pemberian motivasi. Peserta didik diberi penjelasan tentang pokok bahasan, contoh, pemahaman materi yang akan dipelajari. Lalu pada kegiatan inti, peserta didik mendengarkan ceramah tutor. Peserta didik mengerjakan tugas dari tutor, lalu peserta didik mengumpulkan tugas sesuai dengan tema pelajaran. Pada kegiatan penutup ada semacam refeleksi, pemberian tugas, mengadakan test, sama-sama menjawab hasil soal ujian untuk melihat sejauh mana kemampuan peserta didik. Data dan informasi yang ditemukan sesuai dengan Peraturan Menteri Pendidikan Nasional Republik Indonesia Nomor 3 Tahun 2008 tentang standar proses pendidikan kesetaraan program paket c. Pelaksanaan pembelajaran merupakan implementasi dari RPP, meliputi kegiatan pendahuluan, kegiatan inti, dan kegiatan penutup, sehingga pada penerapan RPP PKBM Pusaka Indonesia sudah baik.

\section{Pelaksanaan Kegiatan}

Informasi tambahan tentang pelaksanaan kegiatan paket $C$ ditemukan lebih rinci. Peserta didik melakukan aktivitas pembelajaran melalui jadwal yang sudah dirancang oleh pengurus PKBM. Pak PNY salah satu peserta didik memberikan pernyataan bah- wa, program terlaksana tepat waktu, peserta didik mengikuti kegiatan pembelajaran setiap hari Senin-Kamis menyesuaikan kondisi peserta didik, karena kadang ada acara yang harus dikerjakan dan menjadi prioritas. Program paket $C$ terlaksana sejak tahun 2016, lalu setelah pelaksanaan pembelajaran terdapat ujian tryout, lalu ujian nasional kesetaraan. Informasi tentang jadwal program paket $C$ melalui hasil wawancara dan dokumen semakin mendukung keakuratan data, bahwa jadwal pembelajaran disusun melalui kurikulum paket $\mathrm{C}$.

Proses pembelajaran dilakukan dengan penilaian kedisiplinan peserta didik melalui absensi yang disediakan oleh pengurus. Kedisiplinan menjadi salah satu indikator penilaian sikap peserta didik. Absensi yang disediakan juga diperuntukan kepada tutor. Tutor juga diwajibkan mengisi absensi yang disediakan pengurus.

Proses pelaksanaan pembelajaran menjadi peran penting tutor, karena menjadi faktor penentu, apakah peserta didik mampu memahami dan tertarik mengikuti pelajaran. Kemampuan professional tutor dapat teruji ketika mampu menyajikan materi dengan baik, memiliki kemampuan komunikasi yang baik, lalu mendapatkan umpan balik yang positif dari peserta didik. Keefektifan komunikasi tutor terhadap warga belajar program kesetaraan paket $C$ berdasarkan pemahaman warga belajar dalam pembelajaran yang disampaikan tutor terdiri dari dua indikator yaitu penjelasan tutor, dan penyimpulan tutor (Mulia \& Solfema, 2019). Informasi mengenai efektifitas komunikasi tutor diperoleh dari N sebagai tutor, bahwa peserta didik sangat antusias belajar. Pak PNY menyatakan bahwa tergantung dari tutornya, jika mampu membuat nyaman peserta didik, maka peserta didik akan menjadi antusias. Informasi tambahan melalui keterangan MF bahwa tutor memberikan penjelasan yang sederhana namun dapat dipahami. Proses pembelajaran membuktikan bahwa peserta didik begitu antusias, mereka rajin bertanya bahkan mereka sangat riang mengikuti pembelajaran, ada semangat yang disalurkan oleh tutor, pak $\mathrm{H}$ menambahkan. Aktualisasi pembelajaran memang sangat berpengaruh pada berbagai hal. Menurut (Subali, 2016, p. 21) faktor 


\section{JPPM (Jurnal Pendidikan dan Pemberdayaan Masyarakat), 6 (2), 2019 - 106}

penentu aktualisasi proses pembelajaran antara lain tujuan pendidikan, tenaga pengajar (minat, sikap, pandangan, langgam mengajar, stabilitas emosional, dan lain-lain.). Selain itu Aktualisasi pembelajaran juga didorong oleh biaya yang murah, keinginan warga belajar untuk memperoleh ijazah (Nengsih, Sari, \& Helmi, 2018).

Profesionalitas tutor sebagai tenaga pendidik memang urgen dalam menentukan keberhasilan program pembelajaran, tetapi Peserta didik juga mengambil peran penting dalam proses belajar agar dapat berjalan dengan efektif. Kunci keberhasilan dalam proses pembelajaran peserta didik terletak pada keterlibatan diri mereka dalam proses pembelajaran. Pencapaian efektifitas pembelajaran, ditentukan pula dari strategi pembelajaran dan pendekatan pembelajaran yang diterapkan (Kaniati \& Kusmayadi, 2013). Untuk mencapai standar yang diinginkan, tutor berperan sebagai pembuat metode pembelajaran.

Suasana belajar tentunya dirasakan melalui interaksi secara langsung antara tutor dan peserta didik, seperti keaktifan peserta didik memberi pertanyaan dan menjawab pertanyaan. Kemampuan tutor menciptakan suasana belajar yang nyaman dengan memberikan kebebasan peserta didik untuk bertanya dan menyesuaikan kemampuan peserta didik membuat hubungan tutor dan peserta didik menjadi harmonis. Pendekatan ini juga diungkapkan (Umar \& Redjeki, 2018) bahwa Kegiatan saat proses belajar mengajar, meliputi (1) Memberikan kebebasan berpikir dan tidak memaksa dalam mengerjakan tugas atau menerima mata pelajaran tertentu. Tutor menggunakan beberapa metode tertentu yang dianggap kontekstual. Sesuai pendapat (Aedi, 2016, p. 215) metode pembelajaran terdiri atas metode untuk pembelajaran individual dengan teknik magang, modal, kerjakan sendiri, dan tutorial; metode pembelajaran kelompok seperti kuliah, ceramah, diskusi dan tugas kelompok.

Orientasi peserta didik untuk bekerja diperusahaan memerlukan suatu proses pengenalan situasi kerja atau semacam bimbingan karir. Informasi kemudian diperoleh dari ibu E selaku pengurus, beliau mengatakan bahwa bimbingan karir ternyata bukan bagian dari program PKBM Pusaka Indonesia, tetapi bimbingan karir selanjutnya akan ditangani oleh perusahaan secara langsung, jadi pihak PKBM hanya mempersiapkan peserta didik memperoleh ijazah dan memastikan bahwa peserta didik telah bekerja di perusahaan. Bimbingan karir dilakukan setelah peserta didik diterima perusahaan, akan ada semacam magang selama kurang lebih 3 bulan, maka selanjutnya barulah tanda tangan kontrak untuk melihat seberapa besar kemauan dan kemampuan peserta didik. Hasilnya diharapkan memberikan efek yang positif bagi perusahaan.

Pelaksanaan program paket $\mathrm{C}$ telah memenuhi standar, seperti yang sudah ditetapkan pemerintah. RPP diimplementasikan sesuai dengan rancangan awal (terdapat kegiatan pendahuluan, kegiatan inti dan kegiatan akhir) dan tidak menyimpang dari ketentuan. Pada pelaksanaan program sesuai dengan jadwal yang sudah ditentukan. Terjadi interaksi yang baik antara tutor dan peserta didik sehingga memunculkan hubungan yang harmonis antara tutor dan peserta didik. Akibatnya peserta didik menjadi lebih aktif, disiplin mengikuti program karena semangat untuk belajar. Pada tahap pengembangan pihak perusahaan selanjutnya yang mengambil alih sesuai bidang yang digeluti peserta didik.

\section{Hasil Program Paket C}

Keberhasilan suatu program dapat dilihat dari aspek penilaian, yakni hasil dari program paket $C$ dalam upaya memberdayakan masyarakat Kampung Tumbit Dayak. Pembahasan mengenai hasil program paket $C$ dilihat dari beberapa aspek, mulai dari perubahan peserta didik, kemampuan peserta didik untuk lulus lalu memperoleh ijazah paket $C$ sehingga dapat dipergunakan untuk bekerja. Lalu program juga berdampak pada kemampuan peserta didik untuk memberdayakan diri melalui konteks ekonomi dan kesempatan kerja.

\section{Perubahan Peserta Didik}

Penyelenggaraan paket $C$ di Kampung Tumbit Dayak memberikan perubahan terhadap peserta didik. Ada beberapa aspek mengenai hasil belajar dari peserta didik. 


\section{JPPM (Jurnal Pendidikan dan Pemberdayaan Masyarakat), 6 (2), 2019 - 107}

Menurut pendapat (Sudjana, 2010) bahwa hasil belajar siswa/peserta didik pada hakikatnya adalah perubahan tingkah laku sebagai hasil belajar dalam pengertian yang lebih luas mencakup bidang kognitif, afektif, dan psikomotorik. Secara faktual perubahan peserta didik dapat dilihat pada ujung pembelajaran. Berdasarkan wawancara mendalam dengan tutor, diketahui bahwa metode yang diterapkan dalam meningkatkan kemampuan peserta didik adalah dengan membangun kesadaran untuk percaya diri, pemberian motivasi secara berkala sehingga memicu semangat belajar peserta didik. Ketika kesadaran untuk berubah muncul, maka peserta didik mulai bertindak secara serius dan bersungguh-sungguh belajar. Sikap menjadi aspek utama dalam penilaian. Di dalam dokumen standar kompetensi lulusan-satuan pendidikan paket $C$, bahwa penilaian terutama memang ada pada aspek sikap. Peserta didik berperilaku sesuai dengan ajaran agama yang dianut, menunjukkan sikap percaya diri, bertanggung jawab atas perilaku, perbuatan dan pekerjaannya. Menghargai ragam suku, agama, ras, serta golongan sosial ekonomi dalam lingkup global. Berkomunikasi lisan dan tulisan secara santun. Perubahan sikap pada peserta didik melalui sebuah proses panjang dan sebuah metode pedagogik yang diterapkan oleh pengurus yang diturunkan kepada tutor. Melalui langkah-langkah sistematis dengan membangun kesadaran penuh kepada peserta didik sebagai masyarakat yang pernah gagal pada pendidikan formal untuk lebih semangat, terlebih adanya motivasi dan tujuan pasti di depan.

Peserta Didik Memperoleh Ijazah dan Bekerja di Perusahaan

Berdasarkan kurikulum yang sudah ditetapkan, maka ujian diadakan untuk mengetahui tingkat kemampuan peserta didik. Semua peserta didik yang mengikuti peraturan dan prosedur PKBM mampu lulus ujian. Data dibuktikan melalui daftar peserta didik yang lulus pada berkas lampiran, tentang daftar peserta didik yang lulus ujian. Standar harus dipenuhi oleh peserta didik ketika mendapatkan ijazah, maka dilakukan analisis dokumen pada kurikulum paket $\mathrm{C}$. Terdapat syarat ketuntantasan belajar pada kurikulum paket $\mathrm{C}$, ketentuan belajar setiap indikator yang dikembangkan sebagai suatu pencapaian hasil belajar dari suatu kompetensi dasar berkisar antara 0-100\%. Kriteria ideal ketuntasan untuk masing-masing Indikator $75 \%$ pengelolah harus menentukan kriteria ketuntasan minimal target pencapaian kompetensi (TPK) dengan mempertimbangkan tingkat kemampuan rata-rata peserta didik serta kemampuan sumber daya pendukung dalam penyelenggaraan pembelajaran.

Hasil penilaian peserta didik melalui analisis dokumen, ditemukan bahwa Peraturan Menteri Pendidikan Nasional Republik Indonesia, Nomor 3 Tahun 2008 tentang standar pendidikan kesetaraan paket $C$, penilaian hasil belajar untuk memperoleh ijazah program paket $C$ dilakukan setelah peserta didik mencapai SKK yang diisyaratkan (Menteri Pendidikan Nasional Republik Indonesia, 2008). Hasil belajar beberapa peserta didik menunjukkan bahwa, data ratarata nilai pak MF sebesar tujuh puluh delapan memenuhi standar dan dinyatakan lulus ujian, lalu ijazah digunakan sebagai berkas untuk bekerja. Informasi tambahan dari pak PNY memperoleh nilai rata-rata tujuh puluh delapan, sehingga pak PNY dapat memenuhi standar dan dinyatakan lulus dalam program paket C. Keterangan dari peserta didik dan tutor mengenai peserta didik yang mengikuti ujian dan lulus dengan standar kompetensi lulusan yang sudah ditetapkan, berhak memperoleh ijazah paket $C$ dan digunakan sebagai syarat bekerja di perusahaan (PT. PAMA). Hasil penyelenggaraan program paket $C$ sesuai dengan pernyataan (Kirana, 2018) yang juga menunjukkan bahwa, telah banyak warga masyarakat yang terlayani oleh adanya program ini. Ijazah yang diperoleh alumni, dipergunakan untuk bekerja.

Hasil penyelengaraan paket $C$ dapat dikatakan berhasil, karena Keberhasilan pembelajaran juga dapat dilihat dari tingkat keterserapan lulusan pada dunia kerja setelah selesai pembelajaran di program paket $\mathrm{C}$ (Ernawati \& Mulyono, 2017).

Pemberdayaan Masyarakat (Peserta Didik Mampu Memenuhi Kebutuhan Pokoknya) 


\section{JPPM (Jurnal Pendidikan dan Pemberdayaan Masyarakat), 6 (2), 2019 - 108 Muhamad Ali Salman, Entoh Tohani}

Hasil program paket $C$ tidak hanya dilihat dari segi keterserapan kerjanya, tetapi juga dapat dilihat dari dampak lain yang ditimbulkannya. Menurut (Suhaenah, 2016), implikasi pendidikan kesetaraan paket $\mathrm{C}$ adalah pekerjaan, pendapatan, dan kesejahteraan sosial. Hasil program paket $C$ memiliki dampak lebih jauh, dimana masyarakat dapat memberdayakan diri sehingga mencapai kesejahteraan sosial. Jika melihat teori tentang keberdayaan masyarakat, menurut (Mardikanto \& Soebiato, 2012) indikator keberdayaan masyarakat adalah Kebebasan mobilitas: (kemampuan individu untuk pergi sendirian, ke pasar, rumah sakit, bioskop, rumah ibadah); Kemampuan membeli komoditas kecil: (kebutuhan sehari-hari, keluarga, diri sendiri, dengan keputusan sendiri); Kemampuan membeli komoditas besar: (kemampuan membeli barang tersier dan sekunder (televisi, radio, koran,) dengan uang sendiri); Jaminan ekonomi dan kontribusi terhadap keluarga: memiliki rumah, asset, tabungan.

Kebutuhan peserta didik dilandasi oleh motif ekonomi untuk memperoleh keadilan sebagai masyarakat setempat. Kebutuhan bukan hanya pada peserta didik yang mengikuti program tetapi juga dirasakan oleh pihak keluarga. Adanya ijazah paket $\mathrm{C}$ membuat peserta didik dapat bekerja di perusahaan dan dapat memenuhi kebutuhan ekonominya (kebutuhan pokok serta kebutuhan harihari). Sesuai dengan pendapat (Widjajanti, 2011; Yefni, 2018) bahwa program pemberdayaan secara umum memiliki tujuan untuk menciptakan kondisi yang berkembang, berdaya dan mandiri.

Data dan informasi di lapangan menunjukkan bahwa penyelenggaraan program paket $\mathrm{C}$ memberikan hasil yang baik terhadap peserta didik. Melalui keterangan PNY, H, dan MF bahwa pendapatan mereka meningkat setelah bekerja di perusahaan. Mereka mampu membeli kebutuhan pokok, kebutuhan sehari-hari, dan kebutuhan keluarga baik untuk pendidikan maupun kesehatan.

\section{SIMPULAN}

Pada pelaksanaannya, PKBM Pusaka Indonesia telah memenuhi syarat pembelajaran yang ditetapkan oleh pemerintah. RPP diimplementasikan melalui tiga kegiatan, yaitu kegiatan pendahuluan, kegiatan inti dan kegiatan penutup sesuai standar proses pembelajaran paket C. Pada pelaksanaan kegiatan pembelajaran, tutor mampu membangun kesadaran peserta didik dan menciptakan suasana belajar yang nyaman melalui metode yang sudah dirancang sejak awal. Hal ini dapat dilihat dari tingginya animo peserta didik. Peserta didik yang mengikuti seluruh aturan dan serta memiliki nilai sesuai standar yang ditetapkan, maka dinyatakan lulus dan berhak mendapatkan ijazah paket C. Ijazah kemudian digunakan sebagai syarat bekerja di PT. PAMA dengan menjadi tenaga kerja tetap. Pendapatan peserta didik menjadi meningkat dan cukup untuk memenuhi kebutuhan diri sendiri dan juga memenuhi kebutuhan keluarga, sehingga terjadi proses pemberdayaan masyarakat dalam konteks ekonomi dan kesempatan kerja. Adanya model pemberdayaan masyarakat melalui hubungan kerjasama antara PKBM, aparat kampung dan pihak perusahaan. Hubungan kerjasama tersebut menjadi langkah yang efektif, karena memudahkan dalam menyediakan fasilitas dan tenaga yang dibutuhkan dalam proses penyelenggaraan program pemberdayaan masyarakat kawasan industri pertambangan batubara.

\section{DAFTAR PUSTAKA}

Aedi, N. (2016). Manajemen pendidik dan tenaga kependidikan. Yogyakarta: Gosyen Publishing.

Badan Pusat Statistik Kabupaten Berau. (2016a). Angka partisipasi sekolah. Retrieved from https://beraukab.bps.go.id/

Badan Pusat Statistik Kabupaten Berau. (2016b). Jumlah penduduk Kampung Tumbit Dayak. Retrieved from https://beraukab.bps.go.id/

Ernawati, E., \& Mulyono, S. E. (2017). Manajemen pembelajaran program paket C di PKBM Bangkit Kota Semarang. Journal of Nonformal Education, $\quad 3(1), \quad 60-71$. https://doi.org/10.15294/jne.v3i1.8915

Firdausya, Z. (2016). Efektivitas program kesetaraan kelompok belajar Paket $C$ di 
JPPM (Jurnal Pendidikan dan Pemberdayaan Masyarakat), 6 (2), 2019 - 109 Muhamad Ali Salman, Entoh Tohani

Pusat Kegiatan Belajar Masyarakat 11 Manggarai tahun 2015. Jurnal Risenologi, 1(1), 35-46. Retrieved from http://ejurnal.kpmunj.org/index.php/r isenologi/article/view/23

Haruna, C. N. (2018). Efektivitas program pendidikan kesetaraan Paket B dan C oleh pusat kegiatan belajar masyarakat (PKBM) Cendikia di Kabupaten Pangandaran. Moderat: Jurnal Ilmiah Ilmu Pemerintahan, 4(3), 53-63. https://doi.org/10.25147/moderat.v4i3.1 693

Kaniati, R., \& Kusmayadi, D. (2013). Upaya tutor dalam menerapkan pendekatan pembelajaran mandiri pada warga belajar Paket C di PKBM Pelita Pratama Bandung. EMPOWERMENT: Jurnal Ilmiah Program Studi Pendidikan Luar Sekolah, 2(2), 1-12. https://doi.org/10.2246o/empowermen t.v2i2p1-12.593

Katang, F. M., Rumapea, P., \& Lumolos, J. (2016). Implementasi kebijakan penyelenggara pendidikan kesetaraan program Paket C di Kota Manado. Jurnal Ilmiah Society, 2(20). Retrieved from

https://ejournal.unsrat.ac.id/index.php /jurnalilmiahsociety/article/view/12426

Kirana, N. K. P. (2018). Implementasi program pendidikan kesetaraan Paket $\mathrm{C}$ di sanggar kegiatan belajar (SKB) Kabupaten Sleman. Jurnal Elektronik Mahasiswa Pend. Luar Sekolah-S1, 7(5), 515-526. Retrieved from http://journal.student.uny.ac.id/ojs/ojs /index.php/pls/article/view/12137

Kurniawati, M. (2017). Faktor-faktor yang mempengaruhi pemilihan program kejar paket. In Conference on Management and Behavioral Studies (pp. 128-137). Jakarta: Universitas Tarumanagara.

Mardikanto, T., \& Soebiato, P. (2012). Pemberdayaan masyarakat dalam perspektif kebijakan publik. Bandung: Alfabeta.

Menteri Pendidikan Nasional Republik Indonesia. Peraturan Menteri
Pendidikan Nasional Republik Indonesia nomor 3 tahun 2008 tentang standar proses pendidikan kesetaraan program paket $A$, program paket $B$, dan program paket C, Pub. L. No. 3 (2008). Indonesia.

Miles, M. B., Huberman, A. M., \& Saldaña, J. (2014). Qualitative data analysis: $A$ methods sourcebook. Los Angeles: Sage.

Mulia, W. O., \& Solfema, S. (2019). Gambaran keefektifan komunikasi tutor terhadap warga belajar program kesetaraan Paket C. JFACE: Journal of Family, Adult, and Early Childhood Education, 1(2), 214-222. https://doi.org/10.5281/10.5281/zenodo. 3201768

Nengsih, Y. K., Sari, A., \& Helmi, H. (2018). Pengelolaan pembelajaran program paket $C$ pada pusat kegiatan belajar masyarakat dan sanggar kegiatan belajar di Kota Palembang. JPPM (Jurnal Pendidikan Dan Pemberdayaan Masyarakat), 5(1), 51-6o. https://doi.org/10.21831/jppm.v5i1.1693 6

Oktiwanti, L., Danial, A., \& Syaefuddin, H. (2017). Model pengembangan kemitraan pendidikan non formal dan informal dengan corporate social responsibility (CSR) dalam memberdayakan masyarakat. Jendela PLS, 1(1), 40-51. Retrieved from http://jurnal.unsil.ac.id/index.php/jpls /article/view/131

Prasetyo, G. B. (2015). Partisipasi sosial masyarakat dalam upaya pembangunan pariwisata desa bahasa (Studi di Desa Ngargogondo, Kecamatan Borobudur, Kabupaten Magelang). Jurnal Pendidikan Sosiologi . Retrieved from http://journal.student.uny.ac.id/ojs/in dex.php/societas/article/viewFile/3773 /3575

Presiden Republik Indonesia. UndangUndang Republik Indonesia nomor 20 tahun 2003 tentang sistem pendidikan nasional, Pub. L. No. 20, UndangUndang Republik Indonesia 26 (2003). Indonesia. 
Sopandi, A. (2002). Strategi pemberdayaan masyarakat sekitar kawasan industri. Paradigma: Jurnal Ilmu Pengetahuan Agama, Dan Budaya, 3(2), 13-21. Retrieved from Paradigma: Jurnal Ilmu Pengetahuan Agama, dan Budaya

Subali, B. (2016). Prinsip asesmen dan evaluasi pembelajaran. Yogyakarta: UNY Press.

Sudjana, N. (2010). Penilaian hasil proses belajar mengajar. Bandung: PT Remaja Rosdakarya.

Suhaenah, E. (2016). Implikasi pendidikan kesetaraan paket C terhadap peningkatan taraf hidup warga belajar di SKB kota Serang. Jurnal Eksistensi Pendidikan Luar Sekolah (e-Plus), 1(1). https://doi.org/10.30870/eplus.vii1.1186

Sukmadinata, N. S. (2009). Metode penelitian pendidikan. Bandung: PT Remaja Rosdakarya.

Tohani, E. (2009). Evaluasi pelaksanaan program pusat kegiatan belajar masyarakat (PKBM) dalam konteks pemberdayaan masyarakat di Daerah Istimewa Yogyakarta. Jurnal Penelitian Ilmu Pendidikan, 2(2). https://doi.org/10.21831/jpipfip.voio.461 8

Umar, M., \& Redjeki, E. S. (2018). Pendekatan humanistik dalam proses pembelajaran program pendidikan kesetaraan Paket C. Jurnal Pendidikan Nonformal, 13(2), 70-77.

https://doi.org/10.17977/umo41v13i2p7 o-77

Widjajanti, K. (2011). Model pemberdayaan masyarakat. Jurnal Ekonomi Pembangunan, 12(1). Retrieved from http://hdl.handle.net/11617/1306

Yefni, Y. (2018). Analisi model pemberdayaan masyarakat. Madani: Jurnal Kajian Islam Dan Pengembangan Masyarakat, 3(2). Retrieved from http://ejournal.uinsuska.ac.id/index.php/jmm/article/vie w/6362 